\title{
Current position of legislative approaches to the grant of patent law on isolated human genes
}

\author{
Obecna pozycja podejść legislacyjnych do przyznania prawa patentowego \\ na wyizolowane geny ludzkie
}

\author{
Danielius Serapinas ${ }^{1,2}$, Diana Bekasene ${ }^{3}$, Rita Bandzeviciene ${ }^{1}$, Andrius Narbekovas ${ }^{4}$, Antanas Valantinas ${ }^{1}$ \\ ${ }^{1}$ Institute of Psychology, Mykolas Romeris University, Vilnius, Lithuania \\ Head of the Institute: Assoc. Prof. Antanas Valantinas \\ 2Department of Family Medicine, Medical Academy, Lithuanian University of Health Sciences, Kaunas, Lithuania \\ Head of the Department: Prof. Leonas Valius \\ ${ }^{3}$ International School of Law and Business, Lithuania \\ Head of the School: Gintautas Šiškus \\ ${ }^{4}$ Department of Teology, Vytautas Magnus University, Kaunas, Lithuania \\ Head of the Department: Prof. Andrius Narbekovas
}

Key words: patent law, human genes, DNA.

Słowa kluczowe: prawo patentowe, geny ludzkie, DNA

As medical research is in rapid flux, the scope and variety of inventions in the biotech field is very promising, and gene patents remain important around the world. The international patent law sets the main task to harmonise the basic technical things among the countries. The US Patent and Trademark Office (USPTO) issues thousands of patents for human genes identified by the HGP (Human Genome Project), and it is reasonable to believe that this trend will continue as the HGP isolates and identifies more human genes [1] This increase is not evident only in the United States, but also in the European Union. But the patentability of genes and sequences of human genes has become the subject of hot debate and considerable controversy, both in the conceptual field and in the legal. One of the key issues in biotech patenting is the existence of conflicting legal and ethical criteria.

The aim of this article is to overview the most important legal and ethical aspects of gene patenting in the core countries, particularly the USA and the European Union. Other countries around the world have different approaches towards gene patenting, adjusting variations of those now applied in Europe or the U.S. to their own national juridical, economic, and political context.

The U.S. patent system is recognised as being the broadest patent protection system, especially in the biotechnology field. U.S. patent law arises from the U.S. Constitution [2]. The product for which the patent is being sought must meet stated levels of novelty, utility, and non-obviousness. The statutory patentability require- ments are applied to biotechnology, including DNA sequences, in the same way as they are applied to any other invention [3]. However, there are still many individuals who believe that DNA sequences do not satisfy the basic criteria for patentability: novelty, utility, and non-obviousness. The historical discourse in the U.S. on patenting genes traditionally starts from the case of the Association for Molecular Pathology vs. Myriad Genetics, in which the U.S. Supreme Court held that naturally isolated DNA is not patentable, but that synthetic DNA is patentable [4]. The Court held that isolated human genes cannot be patented because they are not a product of nature and not man-made, and specific gene separation from the rest of the genetic material is not a sufficient condition for the patenting [5]. Professor Watson makes the argument that "human genes should not be patented because DNA is a unique molecule different from other chemicals and should be treated as such". Association for Molecular Pathology v. Myriad Genetics says that corporate efforts to appropriate human DNA is not only unethical but also unfounded because isolated genes are not created by humans [6]. To answer the question "Are human genes patentable?" the Supreme Court decision was focused on the "product of nature" exception. The Court indicated that synthetic DNA sequences designed by the artificial coping method can be considered as intellectual property because they are not natural.

In Europe the argument is that DNA sequences should not be granted patent protection because this violates public order or morality, relying on the Directive and the European Patent Convention (EPC). Separate 
articles of the EU Directive identify potential inventions, i.e. biological material (Article 2 (2)), "manner of manufacture", or the process of getting the material. All these inventions are recognised as patentable if they meet the general requirements of patentability. However, even if the biological material or "manner of manufacture" were to be recognised as inventions, they could join the list of unpatentable objects, enshrined in EU Directive and in a few EPC articles. These documentations articulate that "the human body cannot constitute patentable inventions, an element isolated from the human body, or a partial sequence of a gene" [7]. Unpatentable are "processes for cloning human beings, processes for modifying the germ line genetic identity of human beings, uses of human embryos for industrial or commercial purposes, processes for modifying the genetic identity of animals" [7]. Moreover, bearing in mind that patents are mostly acquired for the economic benefit of the invention, and the invention must have industrial applicability, it is possible to predict the non-patentability of pluripotential human embryonic stem cells. The EU Directive article 5, paragraph 2, states "An element isolated from the human body or otherwise produced by means of a technical process, including the sequence or partial sequence of a gene, may constitute a patentable invention, even if the structure of that element is identical to that of a natural element" [8].

Thus, there is not one unified patent system around the world. The validities of patents, generally applicable rules, and policies in relation to patents of the states vary depending on the specific standards or rules. Therefore, it is necessary to remember the Convention on Human Rights and Biomedicine in which Article 2 states "The interests and welfare of the human being shall prevail over the sole interest of society or science" [9]. It should be noted that, in its essence, the Convention is in force in the old continent in two main documents regulating biotechnology inventions status, i.e. the European Patent Convention on Human Rights (EPC) [7], adopted in 1973, and Directive of the legal protection of biotechnological inventions (EU Directive), adopted in 1998. To talk about this legislation is important because in 1999 the EPO Administrative Council incorporated the individual articles of the EU Directive on the EPC to harmonise patent issuance policies in Europe. The EU Directive emphasises that "Member States shall protect biotechnological inventions under national patent law. They shall, if necessary, adjust their national patent law to take account of the provisions of this Directive”. The latter provision implies uniform rules of law-making ambition in patent law at the regional level.

Comparing U.S. and European legislative [10] and juridical approaches to the grant of patents on isolated human genes, the worldwide general patentability details are similar, and their content reflects nearly the same characteristics of patentability; only the verbal expression of some details differs. The largest difference is noticeable in the moral and ethical patentabil- ity assessments because there are differences between general law and civil law in both countries [11]. The United States falls into the sphere of moral neutrality. Jasanoff (2011), the academician and significant contributor to the field of Science and Technology Studies, believes that the European Patent legal system is more appropriate for its approach to human morality and dignity. Human is valuable in itself, created by nature [12]. There are other ways and methods to heal the human being or disease, not only patenting inventions, which are supposedly created by human diseases. The U.S. does not give importance to morality and focuses instead on economy and social welfare by allowing people to get well in this way, not making any reservations to the patenting of human stem cells [13]. Fundamental human, embryo, isolated human gene rights, and freedom should be respected. In the Convention on Human Rights and Biomedicine an important provision was published, which states that countries of the Convention protect all human dignity and identity, and without discrimination ensure respect for everyone's integrity and other rights, and fundamental freedoms in the fields of biology and medicine [7].

The world patent system is based on the main characteristics of patenting, i.e. inventions must meet the following general criteria: novelty, utility, and non-obviousness [14]. In addition, the invention must comply with the requirements to public order and morality, and this is especially important when dealing with isolated human gene patenting.

If we compare the position of legislative approaches to the grant of patent law on isolated human genes in the European Union and the U.S., the United States should be considered as interpreting patent laws more rigidly; patenting human DNA is considered not only unethical but also unfounded, because isolated human genes are not created by humans [15]. Patents that may violate imperative provisions of the legislation or do not meet the expectations of the public are not granted, and if they were granted in the first years of inventions implementation, but they are challenged by stakeholders as violating societal norms, no matter whether it is ethical, moral, social, or economic [16].

The Subcommittee for Biotechnology and Plant Variety Rights of the International Association for the Protection of Intellectual Property (AIPPI) in its Position Paper (2017) states the undesirable lack of international harmonisation in the patentability of isolated nucleic acid molecules. The AIPPI comments: "While the patenting of genetic material remains controversial, if patent law exists to incentivise the introduction of useful innovations to society, then it should ensure that patents are available for novel, inventive, and industrially applicable developments where something valuable is made available to the public, which it previously did not have. Governments are urged to address this lack of international harmonisation" [17]. 


\section{Conflict of interest}

The authors declare no conflict of interest.

\section{References}

1. Jensen K, Murray F. Intellectual property. Enhanced: intellectual property landscape of the human genome. Science 2005; 310: 239-240.

2. U.S. Constitution, Art. 1, Sec.8, Par. 8. "To promote the Progress of Science and useful Arts, by securing for limited Times to Authors and Inventors the exclusive Right to their respective Writings and Discoveries".

3. Samantha A, Jameson. A comparison of the patentability and patent scope of biotechnological inventions in the United States and the European Union. American Intellectual Property Law 2009; 35: 193-202.

4. The Convention on Human Rights and Biomedicine. The Convention on the Protection of Human Rights and Dignity of the Human Being with regard to the Application of Biology and Medicine, Oviedo, 1997.

5. Supreme court of the United States, Association for Molecular Pathology v. Myriad Genetics, Certiorari to the United States Court of Appeals for the Federal Circuit, no. 12-398, 2013. https://www.supremecourt.gov/opinions/12pdf/12-398_1b7d.pdf

6. Brinckerhoff C $\bar{C}$. Supreme Court Grants Cert In Myriad To Decide If Human Genes Can Be Patented“, 2012. https:// www.pharmapatentsblog.com/2012/11/30/supremecourt-to-decide-if-human-genes-can-be-patented/

7. Europe Patent Convention on Human Rights (EPC), 2016 http://www.epo.org/law-practice/legal-texts/epc.html

8. Ghidini G. Rethinking Law. Rethinking Intellectual Property. Balancing Conflicts of interest in the Constitutional Paradigm. Edward Elgas Publishing, Inc., 2018.

9. Convention on Human Rights and Biomedicine, Convention for the Protection of Human Rights and Dignity of the Human Being with regard to the Application of Biology and Medicine: Convention on Human Rights and Biomedicine, Oviedo, 4.IV.1997.

10. Hawkins N. Human gene patents and genetic testing in Europe: a reappraisal. Scripted 2010; 7: 453-473.

11. World Health Organization. Report of the intergovernmental working group on public health, innovation and intellectual property. World Health Organization 2008.

12. Jasanoff S. Designs on Nature: Science and Democracy in Europe and the United States. Princeton University Press 2011.

13. NIH Public Access, David B. Resnik. Embryonic Stem Cell Patents and Human Dignity. Health Care Anal. 2007; 15: 211-222.

14. Rogers EJ. Can you patent genes? Yes and no. J Pat Trademark Off Soc 2010; 93, 19.

15. Singh KK. Biotechnology and Intellectual Property Rights. Legal and Social Implications 2015

16. The Norwegian National Research Ethics Committees, Bomann-Larsen L. Research ethics and patents, 2016.

17. The Subcommittee for Biotechnology and Plant Variety Rights. Position Paper on Gene Patenting, 16 August 2017 http://aippi.org/wp-content/uploads/2017/08/Gene-Patenting-AIPPI-Position-Paper.pdf

\section{Address for correspondence:}

\section{Danielius Serapinas}

Institute of Psychology

Mykolas Romeris University

Vilnius, Lithuania

Ateities 20, Vilnius LT-08303, Lithuania

Phone: +37 052798182

Fax: +37037326953

E-mail: dserapinas@gmail.com 